\title{
VARIABILITY IN THE PRODUCTION OF EXTRACELLULAR ENZYMES BY ENTOMOPATHOGENIC FUNGI GROWN ON DIFFERENT SUBSTRATES
}

\author{
Elio Gomes Fernandes ${ }^{1}$, Henrique Maia Valério ${ }^{2}$, Thaisa Feltrin ${ }^{3}$, Sueli Teresinha Van Der Sand ${ }^{1^{*}}$ \\ ${ }^{1}$ Universidade Federal do Rio Grande do Sul, Departamento de Microbiologia, Imunologia e Parasitologia, Porto Alegre, RS, \\ Brasil; ${ }^{2}$ Universidade Estadual de Montes Claros, Departamento de Ciências Biológicas e da Saúde, Montes Claros, MG, Brasil; \\ ${ }^{3}$ Universidade FEEVALE, Novo Hamburgo, RS, Brasil.
}

Submitted: March 27, 2011; Returned to authors for corrections: August 29, 2011; Approved: January 16, 2012.

\begin{abstract}
Entomopathogenic fungi are important controllers of pest-insects populations in agricultural production systems and in natural environment. These fungi have enzymatic machinery which involve since the recognition and adherence of spores in their hosts culminating with infection and death of these insects. The main objective of this study was to analyzed extracellular enzyme production of the fungi strains Beauveria bassiana, Metarhizium anisopliae and Paecilomyces sp when cultured on substrates. These fungi were grown in minimal media containing specific substrates for the analysis of different enzymes such as amylases, cellulases, esterases, lipases, proteases (gelatin and caseinase), pectinases and cuticles of Musca domestica larvae and adults. All the assays were performed with and without the presence of dextrose in the culture media. The quantification of enzyme activity was performed by the ratio of halo / colony (H/C) and the results subjected to variance analysis level of 5\% (ANOVA) followed by post-Tukey test. All strains were positive for lipase and also they showed a high significant enzyme production for gelatin at concentrations of 4 and 1\%. B. bassiana and Paecilomyces sp. were positive for amylase, pectinase and caseinase, and only Paecilomyces sp. showed cellulase activity.
\end{abstract}

Key words: Metarhizium anisopliae, Beauveria bassiana, Paecilomyces sp., extracellular enzymes.

\section{INTRODUCTION}

Fungi in general are well characterized microorganisms due to their capacity to produce different extracellular compounds; some of them are biologically very important causing severe reactions in other organisms $(1,5,11)$. These compounds include different types of enzymes and biologically active molecules. The function of this compounds, in pathogenicity, include insects cuticle dissolution, suppression of the immune system, interference with ion channels and other cellular functions in the host cell $(7,6)$. Entomopathogenic fungi are able to cause infection to their hosts simply because the germinated spores have the ability to penetrate directly through the insect's cuticle by enzymatic hydrolysis. The

*Corresponding Author. Mailing address: Universidade Federal do Rio Grande do Sul, Departamento de Microbiologia, Imunologia e Parasitologia. Rua Sarmento Leite, 500 Sala 158, Porto Alegre - RS - Brasil, CEP: 90050-170.; E-mail: svands@ufrgs.br 
entomopathogenic fungi produce a range of cuticle degrading enzymes corresponding to different polymers of the insect cuticle (6).

Some fungi produce enzymes to convert the insect's tissues in nutrients for their growth. Sclerotized insects cuticle are rarely used by the fungi, however, the entomopathogenic fungi produced efficient enzymes to degrade this protective layer of insects $(4,6)$.

St. Leger et al. (19) reported that M. anisopliae var. anisopliae, B. bassiana and Verticilium lecanii produced a large amount of extracellular enzymes such as endoproteases, aminopeptidases, lipases, esterases and chitinases when grown on cuticle of the locust Schistocerca gregaria. The protease Pr1 from M. anisopliae var. anisopliae was able to remove $25-30 \%$ of the cuticle proteins showing that proteases were involved in the hydrolysis of the cuticle and thus facilitating the penetration through the tegument (19). St. Leger et al. (20) in their study observed large variations, in the levels of enzyme production among different isolates of entomopathogenic fungus. Thus all isolates showed high production of endoproteases (20).

Considering relevant to design strategies with a view in microbial control of insects, the aim of this study was to investigate the production of extracellular enzymes of the entomopathogenic fungi Metarhizium anisopliae, Beauveria bassiana and Paecilomyces sp when grown on different substrates in the presence or absence of glucose on the media looking for the possibility to use these strains in insect control.

\section{MATERIALS AND METHODS}

\section{Fungal strains}

All the three fungal strains Metarhizium anisopliae GC 312, Beauveria bassiana CG 470 and Paecilomyces sp. CG 301 were obtained as lyophilized stock culture from Cenargen/Embrapa-Brazil collection of entomopathogenic fungi, Brasília $-\mathrm{DF}$. This strains were used in order to evaluate the production of extracellular enzymes in solid media. Solutions containing $10^{8}$ spores $/ \mathrm{mL}$ for each strain were prepared. Sterile $5 \mathrm{~mm}$ discs of Whatman No. 1 filter paper were soaked in the spore solutions and left to dry and afterwards they were used as culture inoculum's.

\section{Culture conditions}

Minimal medium (MM) was prepared with: $0.6 \%$ of $\mathrm{NaNO}_{3}, 0.05 \%$ of $\mathrm{KH}_{2} \mathrm{PO}_{4}, 0.05 \%$ of $\mathrm{MgSO}_{4}, \mathrm{pH} 6.5$ (5). After sterilization $2 \%$ of a salt solution containing $2.6 \%$ of $\mathrm{KCL}$, $2.6 \%$ of $\mathrm{MgSO}_{4}, 7.6 \%(\mathrm{w} / \mathrm{v})$ of $\mathrm{KH}_{2} \mathrm{PO}_{4}$, and $0.04 \%$ of trace elements solution $\left(0.004 \%\right.$ of $\mathrm{Na}_{2} \mathrm{~B}_{4} \mathrm{O}_{7} ; 0.04 \%$ of $\mathrm{CuSO}_{4}$, $0.001 \%$ of $\mathrm{FeSO}_{4}, 0.08 \%$ of $\mathrm{MgSO}_{4}$ and $0.08 \%$ of $\mathrm{ZnSO}_{4}$ ) was added to the MM. For the completion of the media $1 \%$ of a specific carbon source, substrate for each enzyme, was added to the medium (16). All assays were performed with the presence and absence of $0.1 \%$ of glucose onto the media. Plates containing the specific media were inoculated with the discs containing the spores of each strain The discs were placed in the center of each plate. The assays were done in triplicate and plates incubation took place at $25^{\circ} \mathrm{C}$ for at least 7 days.

\section{Enzymes assays}

The enzyme assays were evaluated by adding the minimal medium the substrate of the enzyme as follows: soluble starch $1 \%$ for amylase, carboxymethylcellulose (CMC) $1 \%$ for cellulase, casein $1 \%$ for caseinase. After fungal growth, the halos were revealed by adding lugol for amylase, solution of $10 \%$ trichloroacetic acid (TCA) for caseinase and Congo-red for cellulase (after 15 minutes the dye was removed with a solution of $4 \mathrm{M} \mathrm{NaCl}$ ). Production of protease was observed using $4 \%$ and $1 \%$ of gelatin as substrate in to the minimal medium. After the incubation period saturated $\left(\mathrm{NH}_{4}\right)_{2} \mathrm{SO}_{4}$ was added onto the plate with fungal growth and a clear halo was observed $(16,15)$. The production of protease was also evaluated using as substrate cuticles of larvae and adults of Musca domestica. The cuticles of the larvae were removed by 
beheading them and squeezing the larvae with the fingers to remove the inner contents of them. After this process, the cuticles of both adults and larvae were washed in water dried in an oven at $50^{\circ} \mathrm{C}$ for 2 hours. The exoskeletons were grounded to a fine powder. To obtain the cuticle solution the powder was resuspended in a solution of $1 \%$ potassium tetraborate and subjected to steam for 20 minutes (2 apud 23). This solution was added to the minimal medium at a final concentration of $1 \%$. The proteolytic activity was verified by pouring in to the petri dish a 10\% trichloroacetic acid solution (22). For pectinolytic activity a minimal medium $\left(\mathrm{K}_{2} \mathrm{HPO}_{4} 7 \mathrm{~g} / \mathrm{L}\right.$, $\mathrm{KH}_{2} \mathrm{PO}_{4} 2 \mathrm{~g} / \mathrm{L},\left(\mathrm{NH}_{4}\right)_{2} \mathrm{SO}_{4} 1 \mathrm{~g} / \mathrm{L}, \mathrm{MgSO}_{4} 0.1 \mathrm{~g} / \mathrm{L}$, agar $15 \mathrm{~g} /$ L) was prepared plus $1 \%$ citrus pectin. After growth of the fungi a solution of hexadecyltrimethylammonium $1 \%$ was added. For esterase analysis the medium used was: peptone 5 $\mathrm{g} / \mathrm{L}$, yeast extract $1 \mathrm{~g} / \mathrm{L}, \mathrm{NaCl} 5 \mathrm{~g} / \mathrm{L}, \mathrm{CaCl}_{2} 0.01 \%$, meat extract $1 \mathrm{~g} / \mathrm{L}$ and agar $15 \mathrm{~g} / \mathrm{L}$, supplemented with $1 \%$ tween 80 . After fungal growth the plates were chilled at $4^{\circ} \mathrm{C}$ for 48 hours (15). To evaluate the lipase activity, the minimal medium was supplemented with $2.5 \%$ olive oil and $0.001 \%$ solution of
Rhodamine B. The isolates with lipolytic activity showed an orange fluorescence around or within the colonies when observed under UV light at $350 \mathrm{~nm}$.

The enzyme activity was determined by the average of the halo $(\mathrm{H})$ diameter of three replicates by the mean diameter of the colony $(\mathrm{C})(\mathrm{H} / \mathrm{C})$ except for lipase where the enzyme production was only observed (16). The results were analyzed using analysis of variance single factor (ANOVA) with significance level of $5 \%$, followed by post-test Tukey with significance level of 0.05 , when necessary (16).

\section{RESULTS AND DISCUSSION}

Fungus Paecilomyces sp. GC 301 and B. bassiana CG 470 showed a higher $\mathrm{H} / \mathrm{C}$ index for amylase activity compared to M. anisopliae CG 312 which presented the lowest $\mathrm{H} / \mathrm{C}$ index (Figures 1-3). The ANOVA analysis showed a significant statistical difference between B. bassiana and Paecilomyces sp. in relation to $M$. anisopliae (Table 1). The addition of glucose in the media showed no improvement in amylase activity for any of the strains (Figures 1-3).

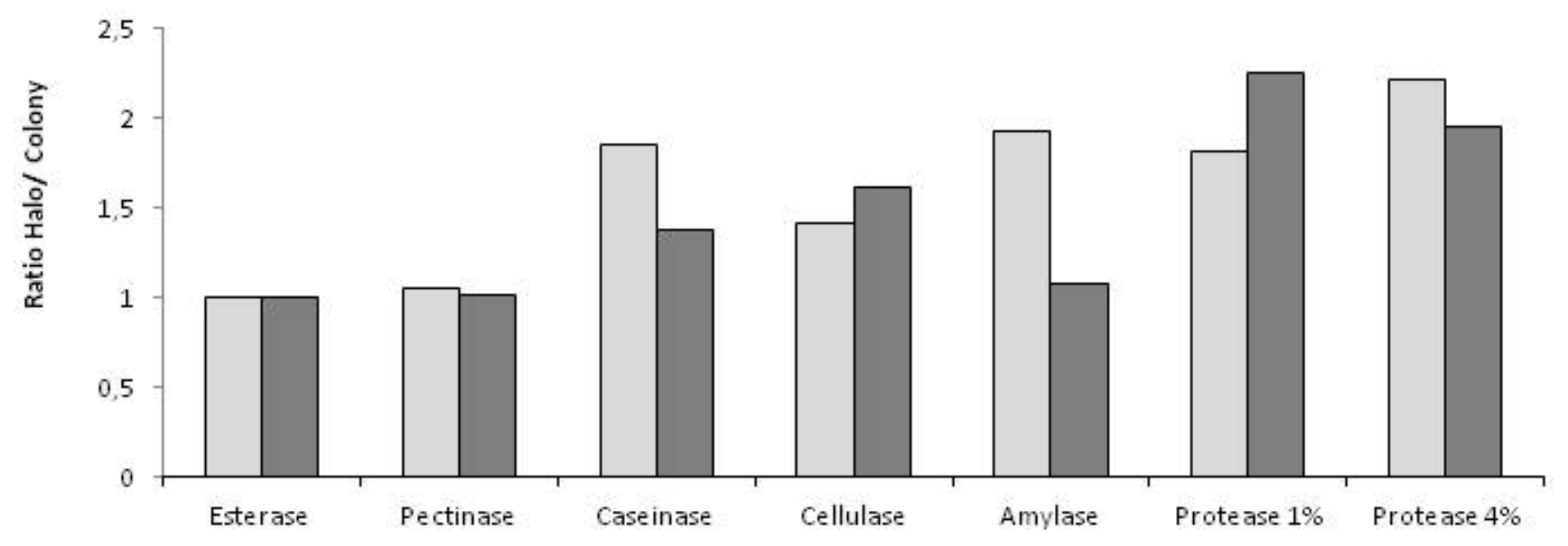

Enzimas

Figure 1. Extracellular enzymes produced by the fungus Paecilomyces sp incubated at $25^{\circ} \mathrm{C}$ for at least 7 days. 


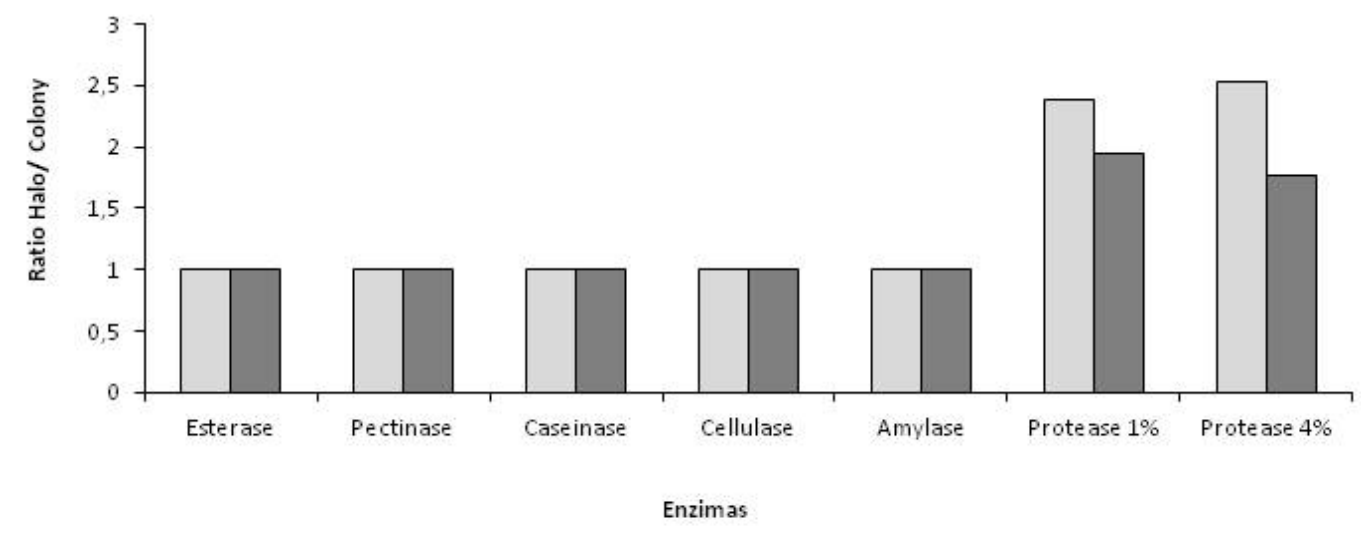

$\square$ Without Glucose $\quad \square$ With Glucose

Figure 2. Extracellular enzymes produced by the fungus $M$. anisopliae incubated at $25^{\circ} \mathrm{C}$ for at least 7 days.

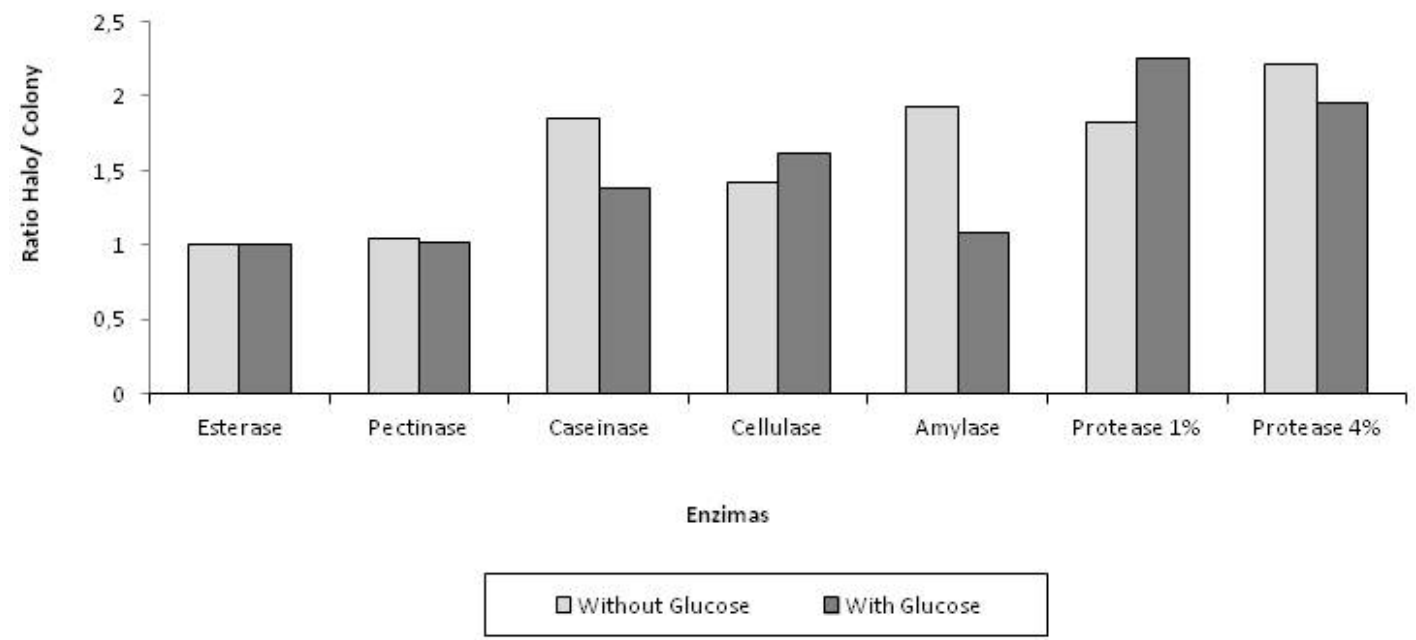

Figure 3. Extracellular enzymes produced by the fungus $B$. bassiana incubated at $25^{\circ} \mathrm{C}$ for at least 7 days.

Fungi can use starch as a source of energy for its development and sporulation (9). Accordingly to Nwufo \& Fajoles (12) the amount of enzyme detected in the culture medium can be a criterion for selection and classification, accordingly to the genus which species are involved. Murad et al (10) in their work were able to determine low concentrations of $\alpha$-amylase produced by $M$. anisopliae growing on Callosobruchus maculatus shelves. This result was expected by the authors because of the lack of starch in the composition of the shelves. The result also indicates that this enzyme is not very important for the infection process since it's not present in the cuticle of the insect.

The enzymatic activity observed for cellulase, showed that Paecilomyces sp. could produce much more enzyme when compared to B. bassiana and M. anisopliae which showed no obvious substrate hydrolysis. The halos were visible only under the region where the mycelium grew (Figures 1-3). The statistical analysis, only Paecilomyces sp. obtained a significant difference $\mathrm{H} / \mathrm{C}$ ratio when compared to other fungi (Table 1).

Similar results were achieved by St Leger et al. (18) when they evaluated cellulose activity for various fungi and they did 
not observed a clear hydrolysis halo for $M$. anisopliae and $B$. bassiana while the fitopathogenic fungi produced halos in culture media containing carboxymethylcellulose.

Fungi are good producers of cellulolytic extracellular enzymes and are widely used in pharmaceutical, agricultural, food, paper, detergent and petroleum industrial processes. The Paecilomyces sp strain with the results obtained for cellulose production might be used for commercial and biotechnological applications (8).

Table 1. Results obtained with the ratio values of Halo/Colony submitted to the Tukey test at a significance level of $0.05 \%$.

\begin{tabular}{|c|c|c|c|c|c|c|}
\hline Enzymes & $\begin{array}{c}\text { CG } 301 \\
\Delta \\
\end{array}$ & $\begin{array}{c}\text { CG } 301 \\
\Delta\end{array}$ & $\begin{array}{c}\text { CG } 470 \\
\Delta\end{array}$ & $\begin{array}{c}\text { CG } 470 \\
\Delta\end{array}$ & $\begin{array}{c}\text { CG } 312 \\
\Delta\end{array}$ & $\begin{array}{c}\text { CG } 312 \\
\Delta\end{array}$ \\
\hline Esterase & $1 \mathrm{a}$ & $1 \mathrm{a}$ & $1 \mathrm{a}$ & $1 \mathrm{a}$ & $1 \mathrm{a}$ & $1 \mathrm{a}$ \\
\hline Pectinase & $1.05 \mathrm{a}$ & $1.02 \mathrm{a}$ & $1 \mathrm{a}$ & $1.05 \mathrm{a}$ & $1 \mathrm{a}$ & $1 \mathrm{a}$ \\
\hline Caseinase & $1.80 \mathrm{a}$ & $1.38 \mathrm{a}$ & $2.25 \mathrm{~b}$ & $1.54 \mathrm{a}$ & $1 \mathrm{a}$ & $1 \mathrm{a}$ \\
\hline Cellulase & $1.44 \mathrm{a}$ & $1.66 \mathrm{~b}$ & $1 \mathrm{a}$ & $1 \mathrm{a}$ & $1 \mathrm{a}$ & $1 \mathrm{a}$ \\
\hline Amylase & $1.85 \mathrm{~b}$ & $1.07 \mathrm{a}$ & $1.38 \mathrm{~b}$ & $1 \mathrm{a}$ & $1 \mathrm{a}$ & $1 \mathrm{a}$ \\
\hline Protease & $1.82 \mathrm{a}$ & $2.26 \mathrm{~b}$ & $2.1 \mathrm{~b}$ & $1.4 \mathrm{a}$ & $2.38 \mathrm{a}$ & $2 a$ \\
\hline Gelatina & $1.92 \mathrm{~b}$ & $1.82 \mathrm{a}$ & $2.21 \mathrm{~b}$ & $1.67 \mathrm{a}$ & $2.54 \mathrm{~b}$ & $1.77 \mathrm{a}$ \\
\hline
\end{tabular}

Means followed the same lowercase letters in the same row do not differ ( $>>0.05$ ).

$\Delta$ culture medium without glucose, $\boldsymbol{\Delta}$ culture medium with glucose.

Legend: CG 301 Paecilomyces sp; CG 470 Beauveria bassiana; CG 312 Metarhizium anisopliae.

All strains showed a low $\mathrm{H} / \mathrm{C}$ index for pectinase activity (Figures 1-3). The strains did not differ significantly using the Tukey test at a significance level of $0.05 \%$ (Table 1). No difference was observed for enzyme activity when the strains were grown on media containing pectin in the presence or absence of glucose. The fungus Paecilomyces sp. showed an increase in enzyme activity when grown in the culture medium without glucose. On the other hand B. bassiana showed a better pectinase activity when grown in medium with glucose and pectin. The production of pectinase by some fungi may denote the phytopathogenic ability that these microorganisms exhibit (3). St Leger et al. (18) in their experiments where B. bassiana and $M$. anisopliae were used as template they observed the absence of halos on plates with medium containing pectin as substrate. These results are in agreement with those obtained in this work. Barbosa et al. (3) related the infection process of the phytopathogenic fungus Cladosporium herbarum to pectinase production, since this enzyme is very important in the infection process of host plant. Potential antagonism of Trichoderma species against $C$. herbarum, the capacity of the pathogen and the antagonist to produce extracellular enzymes like proteases and monoacetyl esterases could be related to the mechanisms of pathogenicity or the antagonistic activity.

The evaluation of esterase activity by the fungi tested in this study showed no differences among them. Therefore, we did not observe the formation of clear halos in the medium recording the enzyme activity only in the region with mycelium growth (Figure 1-3). Although the esterase enzyme has not been quantified in this study, it is known to be a very important step for the adhesion of fungi spores on the insect cuticle and together with proteases, the not germinated spores alter the insect cuticle surface thus promoting the nutrition and germination of conidia (21).

Lipase activity was observed for all strains. St. Leger et al. $(19,20)$ observed a high production of extracellular enzymes (lipase among others) by M. anisopliae and B. bassiana when they were grown in culture media containing locust cuticle. Silva et al (17) were able to extract different amounts of lipase when $M$. anisopliae was cultivated in different carbon sources. The authors related these enzymes with the pathogenicity of the fungus.

B. bassiana and Paecilomyces sp. were good producers of 
caseinase, while M. anisopliae only degraded the substrate under the mycelial growth. The statistic analysis the $\mathrm{H} / \mathrm{C}$ index obtained by Paecilomyces sp., grown in medium containing casein and $0.1 \%$ glucose, differ significantly from the results presented by the other two strains (Table 1).

Tiago \& Silva (22) studying extracellular enzymes activity of $M$. anisopliae, found that all isolates, showed the presence of halo in medium containing casein as the sole carbon source, and some of the isolates produced more enzymes than the others. Pinto et al (14) conducting the study with $M$. flavoviride observed differences in the enzyme assays in liquid media where the only nitrogen source was casein.

In the assays for protease production using $4 \%$ of gelatin as substrate, all three strains showed a high $\mathrm{H} / \mathrm{C}$ ratio for enzyme production. The index was higher when the fungi grew in absence of glucose (Figures 1-3). However, the difference observed was not statistically significant (Table 1). The assays using a low concentration of gelatin the $\mathrm{H} / \mathrm{C}$ index was also high (Figures 1-3). B. bassiana and M. anisopliae showed the highest $\mathrm{H} / \mathrm{C}$ rates when grown in media containing only gelatin as substrate, and the results differ significantly from each other. The fungus Paecilomyces sp. showed higher H/C in culture medium containing $0.1 \%$ glucose, and the results differ statistically from the media without the glucose (Table 1).

Protease production was not observed when the strains grew in media containing insect cuticle. This result might happened because the fungi showed a low concentration of cells in the conditions used. Similar results were obtained by Tiago \& Silva (22) when the authors analyzed the behavior of M. anisopliae on cuticle of Mahanarva fimbriolata and Deois flavopicta. The authors suggested that the protocol for expression of extracellular proteases ( Pr1 and Pr2) should be done using broth media for strains growth. They observed protease production results when they grew $M$. anisopliae in liquid media containing cuticle of various insects such as locusts Schistocerca pallens, Rhammatocerus schistocercoides and Schistocerca gregaria and Manduca sexta moth (13, 14,
23). Murad et al (10) were able to isolate proteases from a culture where $M$. anisopliae grew in minimal medium containg C. maculates cuticle showing that this enzymes are produced in the presence of insect exoskeleton.

In our results, proteases were produced by all strains in the presence of gelatin as substrate. Each specie analyzed in this work, has shown a distinct enzymatic apparatus and the strain Paecilomyces sp. showed the greatest versatility for different enzyme substrates. The results involving the production of extracellular enzymes of entomopathogenic fungi are very important because they reveal its biological and physiological apparatus, showing their specialization in the degradation of various substances found in different hosts or environments.

Future studies to characterize these enzymes and the sequences of their DNA where they are produced it's necessary for the proper understanding of how these fungi behave during infection of their hosts as well as its function as saprophytes in the natural environment.

\section{ACKNOWLEDGEMENTS}

CENARGEN / EMBRAPA-DF by yielding the fungal isolates used in this research and CAPES for scholarship concession for the first author.

\section{REFERENCES}

1. Alves, S.B. (1998). Fungos entomopatogênicos, In: Alves, S.B. Controle microbiano de insetos. Piracicaba, Fealq, p.289-381.

2. Andersen, S.O. (1980). Cuticular sclerotization. In: MILLER, T.A. Cuticle techniques in arthropods. New York: Springer-Verlag, p.185217.

3. Barbosa, M.A.G.; Rehn, K.G.; Menezes, M.; Mariano, R.L.R. (2001). Antagonism of Trichoderma species on Cladosporium herbarum and their enzimatic characterization. Braz. J. Microbiol., São Paulo, 32(2). 98-104.

4. Dias, B.A. (2005). Estudo de Proteases Degradadoras de Cutícula Produzidas Pelo Fungo Entomopatogênico Beauveria bassiana. Londrina. 70p. (M.Sc. Dissertation. Universidade Estadual de Londrina).

5. Dias, B.A.; Neves, P.M.O.J.; Maia, L.F.; Furlaneto, M.C. (2008). Cuticle 
Degrading proteases produced by the entomopathogenic fungus Beauveria bassiana in the presence of coffee berry borer cuticle. Braz. J. Microbiol. 39, 301-306.

6. Fang, W.; Ripoll, M.P.; Wang, S.; Leger, R.S. (2009). Protein kinase A regulates production of virulence determinants by the entomopathogenic fungus, Metarhizium anisopliae. Fungal Genet. Biol. 46(3), 277-285.

7. Freimoser, F.M.; Screen, S.; Bagga, S.; Hu, G.; St. Leger, R.J. (2003). Expressed sequence tag (EST) analysis of two species of Metarhizium anisopliae reveals a plethora of secreted proteins with potential activity in insect hosts. Microbiol. 149, 239-247.

8. Green, B.J.; Beezhold, D.H. (2011). Industrial fungal enzymes: An occupational allergen perspective. J. Allergy, 2011, 11p.

9. Griffin, D.H. (1994). Fungal physioly. $2^{\circ}$ e.d. New York: John Wiley \& Sons.

10. Murad, A.M.; Laumann, R.A.; Lima, T.A.; Sarmento, R.B.; Noronha, E.F.; Rocha, T.L.; Valadares-Inglis, M.C.; Franco, O.L. (2006). Screening of entomopathogenic Metarhizium anisopliae isolates and proteomic analysis of secretion synthesized in response to cowpea weevil (Callosobruchus maculatus) exoskeleton. Comp. Biochem. Physiol. 142(3-4) 365-37.

11. Mustafa, U.; Kaur, G. (2009). Extracellular enzyme production in Metarhizium anisopliae isolates. Folia Microbiol. 54(6), 499-504.

12. Nwufo, M.I.; Fajola, A.O. (1988). Production of amylolytic enzymes in culture by Botryodiplodia theobromae and Sclerotium rolfsii associated with the corns rots of Colocasia esculenta. Acta Microbiol. Hung. 35, 371-378.

13. Paterson, I.C.; Charnley, A.K.; Cooper, R.M.; Clarkson, J.M. (1994). Partial characterization of specific inducers of a cuticle-degrading proteases from the insect pathogenic fungus Metarhizium anisopliae. Microbiol. 140, 3153-3159.

14. Pinto, F.G.S.; Fungaro, M.H.P.; Ferreira, J.M.; Valadares-Inglis, M.C.; Furlaneto, M.C. (2002). Genetic variation in the cuticle-degrading protease activity of the entomopathogen Metarhizium flavoviride. Genet.
Mol. Biol., 25(2), 231-234.

15. Poloni, A. (2008). Estudo da virulência e variabilidade fisiológica e genética do fungo Bipolaris sorokiniana. Porto Alegre, Brasil, 101p. (M.Sc. Dissertation. Programa de pós-graduação em Microbiologia Agrícola e do Ambiente. UFRGS).

16. Poloni, A.; Pessi, I.S.; Frazzon, A.P.G.; Van Der Sand, S.T. (2009).Morphology, physiology, and virulence of Bipolaris sorokiniana isolates. Curr. Microbiol. 59, 267-273.

17. Silva, W.O.B.; Mitidieri, S.; Schrank, A.; Vainstein, M.H. (2005). Production and extraction of an extracellular lípases from the entomopathogenic fungus Metarhizium anisopliae. Process Biochem. 40, 321-326.

18. St Leger, R.J.; Joshi L.; Roberts, D.W. (1997). Adaptation of proteases and carbohydrases of saprophytic, phytopathogenic and entomopathogenic fungi to the requirements of their ecological niches. Microbiol. 143, 1983-1992.

19. St. Leger, R.J.; Cooper, R.M.; Charnley, A.K. (1986a). Cuticledegrading enzymes of entomopathogenic fungi: Cuticle degradation in vitro by enzymes from entomopathogens. J. Invertebr. Pathol. 47, 167177.

20. St. Leger, R.J.; Charnley, A.K.; Cooper, R.M. (1986b). CuticleDegrading Enzymes of Entomopathogenic Fungi: Synthesis in Culture on Cuticle. J. Invertebr. Pathol. 48, 85-95.

21. St. Leger, R.J.; Goettel, M.; Roberts, D.W.; Staples, R.C. (1991). Prepenetration events during infection of host cuticle by Metarhizium anisopliae. J. Invertebr. Pathol. 58, 168-179.

22. Tiago, P.V.; Silva, R.J. (2007). Atividade proteolítica de isolados de Metarhizium anisopliae sobre substratos cuticulares e não-cuticulares. Cienc. Rural, Santa Maria. 37, 1.

23. Tiago, P.V.; Fungaro, M.H.P.; Furlaneto, M.C. (2002). Cuticle-degrading proteases from the entomopathogen Metarhizium flavoviride and their distribution in secreted and intracellular fractions. Lett. Appl. Microbiol., London. 34, 91-94. 